\title{
Curcumin suppresses the proliferation of gastric cancer cells by downregulating H19
}

\author{
GAO LIU $^{1 *}$, TIAN XIANG ${ }^{2 *}$, QUAN-FENG WU ${ }^{1}$ and WEI-XING WANG ${ }^{3}$ \\ ${ }^{1}$ Department of Gastrointestinal Surgery; ${ }^{2}$ Department of Clinical Laboratory Center, \\ Central Hospital of Enshi Autonomous Prefecture, Enshi Clinical College of Wuhan University, \\ Enshi, Hubei $445000 ;{ }^{3}$ Department of Hepatobiliary and Laparoscopic Surgery, \\ Renmin Hospital of Wuhan University, Wuhan, Hubei 430060, P.R. China
}

Received June 7, 2015; Accepted October 18, 2016

DOI: $10.3892 / 01.2016 .5354$

\begin{abstract}
Curcumin, a major phytochemical in turmeric, inhibits the proliferation of many types of solid cancer cells by enhancing p53 expression. However, the long non-coding RNA H19 directly inhibits p53 activation and thus promotes gastric cancer progression. The aim of this study was to assess the role of H19 in curcumin-induced proliferative inhibition of gastric cancer. The gastric cancer cell line SGC-7901 was treated with curcumin at different concentrations and time points. The effect of curcumin on proliferation was assessed using cell counting kit-8 assays and flow cytometry with Ki67 staining. In addition, H19 expression was quantified by reverse transcription-quantitative polymerase chain reaction, and apoptosis was evaluated by flow cytometric detection of Annexin $\mathrm{V}$ and propidium iodide double staining. The protein expression of p53, B-cell lymphoma (Bcl)-2, Bcl-2-associated X protein (Bax) and c-Myc in curcumin-treated cells was detected by western blotting. The present study demonstrated that curcumin inhibited the proliferation of SGC7901 cells and suppressed H19 expression in a concentration-dependent manner, while p53 expression was enhanced. Ectopic expression of H19 in SGC7901 cells reversed curcumin-induced proliferative inhibition and downregulated p53 expression. Furthermore, while curcumin induced cell apoptosis and enhanced the expression ratio of $\mathrm{Bax} / \mathrm{Bcl}-2$, which are downstream molecules of $\mathrm{p} 53$, ectopic expression of H19 inhibited curcumin-induced cell apoptosis. In addition, curcumin decreased the expression of the c-Myc oncogene, and exogenous c-Myc protein reversed the curcumin-induced downregulation of H19 expression.
\end{abstract}

Correspondence to: Professor Wei-Xing Wang, Department of Hepatobiliary and Laparoscopic Surgery, Renmin Hospital of Wuhan University, 238 Jiefang Road, Wuhan, Hubei 430060, P.R. China

E-mail: wang_weixing1956@163.com

*Contributed equally

Key words: curcumin, H19, p53, c-Myc, gastric cancer
These results suggested that curcumin inhibits the proliferation of gastric cancer cells by downregulating the c-Myc/H19 pathway. Therefore, curcumin may be considered a novel therapeutic strategy to inhibit gastric cancer cell growth.

\section{Introduction}

Curcumin, which is commonly called diferuloylmethane, is derived from Curcuma longa, a plant of the ginger family (1). Extensive research over the last half century has revealed the therapeutic potential of curcumin in tumor progression, including inducing apoptosis, inhibiting angiogenesis and enhancing susceptibility to chemotherapy and radiotherapy $(1,2)$. Furthermore, the anticancer effect of curcumin has been confirmed in a number of clinical trials, in which is has been used as a natural chemoprevention agent in colorectal and pancreatic cancer (3-5). Accumulating evidence suggests that curcumin has a diverse range of molecular targets, including c-Myc, cyclooxygenase-2, Notch1, nuclear factor- $\mathrm{\kappa B}$ and p53 (2,6-8).

The tumor suppressor $\mathrm{p} 53$ plays a pivotal role in the etiology of human cancers; it not only controls the cellular proliferation of tumor cells, but is also capable of inducing cell apoptosis (9). Previous studies reported that curcumin induced p53 expression in prostate cancer, $\mathrm{B}$-cell lymphoma (Bcl) cells and breast cancer, and thereby activated the pro-apoptotic downstream genes $\mathrm{p} 21$ and $\mathrm{Bcl}-2$-associated $\mathrm{X}$ protein (Bax) and inhibited Bcl-2 (anti-apoptosis) expression to induce apoptotic progress $(2,10,11)$. Furthermore, curcumin induced cell-cycle arrest by downregulating cyclin D1 expression $(2,10,11)$.

In gastric cancer, curcumin attenuated in vivo tumor growth induced by $\mathrm{N}$-methyl-N-nitrosourea by downregulating the expression of cyclin D1 in tumor cells (12). In in vitro studies, curcumin induced cell apoptosis by reducing $\mathrm{Bcl}-2$ expression or enhancing reactive oxygen species production, and induced a G1 cell cycle arrest by downregulating cyclin D1 expression (12-15). Activation of the phosphoinositide 3-kinase (PI3K)/AKT pathway was also inhibited by curcumin, and played a role in promoting cell apoptosis (16). Although Bcl-2 and cyclin D1 are downstream molecules of p53 (17), and LY294002 (a PI3K inhibitor) was shown to induce p53 expression and p53-dependent apoptosis in gastric cancer cells by 
inhibiting the activation of PI3K/AKT signaling (18), there is not yet sufficient evidence to confirm that curcumin regulates p53 expression in gastric cancer cells.

The long non-coding RNA (lncRNA) H19 is produced from the paternally imprinted $\mathrm{H} 19$ gene and is considered an oncogenic lncRNA in various cancers (19-22). Furthermore, previous studies have reported that H19 is abnormally upregulated in gastric cancer (23-25) and contributes to cellular proliferation by directly inactivating p53 (26). Notably, curcumin downregulated $\mathrm{H} 19$ gene transcription and c-Myc expression in human tumor cells $(2,27,28)$. In addition, the c-Myc oncogene was shown to directly induce H19 expression by binding to the H19 promoter, and thereby promoted the proliferation of gastric cancer cells $(29,30)$.

The present study aimed to determine whether curcumin suppresses the proliferation of gastric cancer cells by regulating c-Myc/H19/p53 signaling. It was confirmed that curcumin inhibited the proliferation of gastric cancer cells, suppressed H19 and c-Myc expression, and enhanced p53 expression in a time- and concentration-dependent manner. Overexpression of H19 in gastric cancer cells reversed curcumin-induced cell apoptosis and the inhibitory effect on cell proliferation, as well as decreasing p53 expression in the presence of curcumin. Furthermore, exogenous c-Myc enhanced H19 expression in gastric cancer cells in the presence of curcumin. Together, these results suggested that curcumin exploited a novel mechanism to inhibit gastric cancer cell growth.

\section{Materials and methods}

Reagent and cell culture. Curcumin (Sigma-Aldrich; Merck Millipore, Darmstadt, Germany) was dissolved in dimethyl sulfoxide (Sigma-Aldrich; Merck Millipore) and stored at $-20^{\circ} \mathrm{C}$ until use. Active human c-Myc full-length protein was purchased from Abcam (Cambridge, MA, USA) and added to media for a final concentration of $5 \mu \mathrm{g} / \mathrm{ml}$ (31). The human gastric cancer cell line SGC7901 and the immortalized human gastric epithelial mucosa cell line GES-1 were obtained from the American Type Culture Collection (Manassas, VA, USA). All cell lines were maintained in RPMI-1640 medium (Hyclone; GE Healthcare Life Sciences, Logan, UT, USA) supplemented with $10 \%$ fetal bovine serum (Gibco; Thermo Fisher Scientific, Inc., Waltham, MA, USA) and cultured in a humidified incubator containing $5 \% \mathrm{CO}_{2}$ at $37^{\circ} \mathrm{C}$. For the c-Myc protocol, recombinant human c-Myc protein $(5 \mu \mathrm{g} / \mathrm{ml})$ was added to the media of SGC7901 cells in the presence of $50 \mu \mathrm{M}$ curcumin.

$R N A$ extraction and reverse transcription-quantitative polymerase chain reaction ( $R T-q P C R)$. RNA was extracted from the cells using TRIzol ${ }^{\circledR}$ reagent (Invitrogen; Thermo Fisher Scientific, Inc.), according to the manufacturer's protocol. RNase-free DNase I (Thermo Fisher Scientific, Inc.) treatment was performed to remove any contaminating DNA. RT-qPCR was performed using the ReverTra Ace- $\alpha$ firststrand cDNA synthesis kit and the SYBR Green Real-time PCR Master mix kit (both Toyobo Co., Ltd., Osaka, Japan). For mRNA detection, the primers used in this study were as follows: H19 forward, 5'-TACAACCACTGCACTACCTG-3' and reverse, 5'-TGGAATGCTTGAAGGCTGCT-3' (32); and GAPDH (as an internal control) forward, 5'-ACCTGA CCTGCCGTCTAGAA-3' and reverse, 5'-TCCACCACC CTGTTGCTGTA-3' (33). The ABI StepOne Plus (Applied Biosystems; Thermo Fisher Scientific, Inc.) was used to perform qPCR. PCR reactions were performed at $95^{\circ} \mathrm{C}$ for $5 \mathrm{~min}$, followed by 40 cycles of $95^{\circ} \mathrm{C}$ for $15 \mathrm{sec}$ and $60^{\circ} \mathrm{C}$ for $1 \mathrm{~min}$. Each experiment was performed in triplicate. The relative mRNA expression levels were determined using the $2^{-\Delta \Delta \mathrm{Cq}}$ method (34).

Transfection. H19 cDNA (GenBank accession no. NR_002196.1) was inserted into the multiple cloning sites of the pcDNA3.1 vector (Invitrogen; Thermo Fisher Scientific, Inc.), as described previously (33). A total of $1 \times 10^{5}$ cells were plated onto 24-well plates for $24 \mathrm{~h}$ and then transfected with $0.5 \mu \mathrm{g}$ plasmid using Lipofectamine 2000 (Invitrogen; Thermo Fisher Scientific, Inc.) for 48 h. The cells were then subjected to RNA/protein extraction or further functional assays.

Cell proliferation assay. Cell proliferation assays were performed using a Cell Counting kit-8 (CCK-8; Beyotime Institute of Biotechnology, Shanghai, China), as described previously (35). Briefly, SGC7901 cells (1x10 4 cells/well) were plated onto 96-well plates, and then treated with curcumin or pre-transfected with pcDNA3.1-H19 or empty vector for $48 \mathrm{~h}$. The number of cells per well was detected by measuring the absorbance $(450 \mathrm{~nm})$ of reduced WST- 8 at various time points using the SpectraMax ${ }^{\circledR}$ i3x microplate reader (Molecular Devices, LLC, Sunnyvale, CA, USA).

Cell apoptosis. Evaluation of cell apoptosis was performed using the FITC Annexin V Apoptosis Detection kit with PI (BioLegend, Inc., San Diego, CA, USA). Briefly, the cells were washed twice with cold BioLegend's Cell Staining Buffer, and then resuspended in Annexin V Binding Buffer at a concentration of $0.25-1.0 \times 10^{7}$ cells $/ \mathrm{ml}$. This suspension $(100 \mu \mathrm{l})$ was stained with $5 \mu \mathrm{l}$ FITC/Annexin V and $10 \mu \mathrm{l}$ PI, after which the cells were gently vortexed and incubated for $15 \mathrm{~min}$ at room temperature $\left(25^{\circ} \mathrm{C}\right)$ in the dark. Subsequently. $400 \mu 1$ Annexin V Binding Buffer was added to each tube, which were analyzed by flow cytometry.

Ki67 staining. The cells were washed twice with PBS by centrifugation at $350 \times \mathrm{g}$ for $5 \mathrm{~min}$ at $4^{\circ} \mathrm{C}$, and then resuspended in $3 \mathrm{ml}$ cold $70 \%$ ethanol and incubated at $-20^{\circ} \mathrm{C}$ for $1 \mathrm{~h}$. Subsequently, the cells were resuspended in $100 \mu \mathrm{l}$ PBS in the presence of phycoerythrin-conjugated anti-human Ki67 antibody (1:20; cat. no., 350504; BioLegend, Inc.), and then incubated at room temperature in the dark for $30 \mathrm{~min}$. Next, $500 \mu \mathrm{l}$ PBS was added to resuspend the cells for flow cytometric analysis.

Western blotting. Proteins were extracted from the cells using radioimmunoprecipitation assay lysis buffer (Beyotime Institute of Biotechnology) and were quantified using a BCA Protein Assay kit (Beyotime Institute of Biotechnology). Proteins $(30 \mu \mathrm{g})$ were separated by $10 \%$ SDS-PAGE and transferred onto polyvinylidene difluoride membranes (EMD Millipore, Billerica, MA, USA). The membrane was 
A

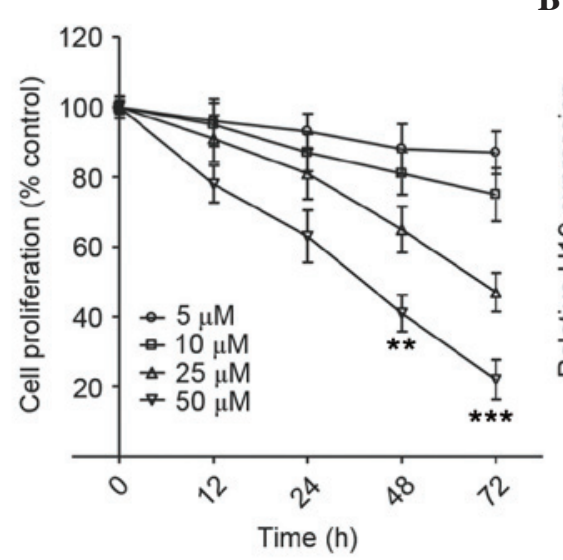

B

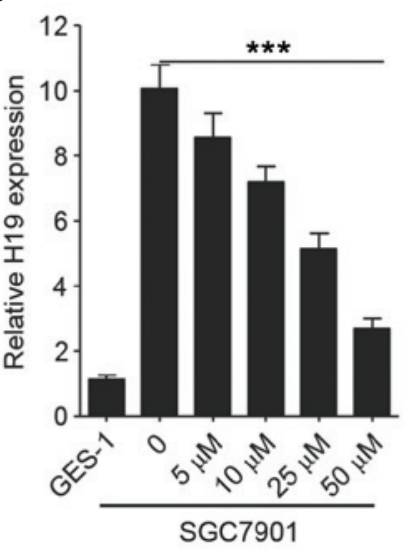

C

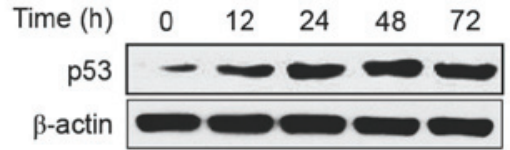

D

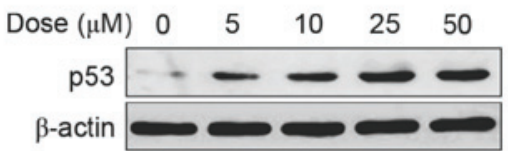

Figure 1. Effect of curcumin on cell proliferation and H19 and p53 expression. SGC7901 cells were treated with different concentrations of curcumin and then collected at different time points. (A) Cell proliferation was assessed using cell counting kit- 8 assays. Data are shown as the mean \pm SD of three separate experiments performed in duplicate. (B) The relative mRNA expression levels of H19 were determined by reverse transcription-quantitative polymerase chain reaction. H19 levels were normalized to the GAPDH level in GES-1 cells. Data are shown as the mean \pm SD of three separate experiments performed in duplicate. (C) Western blotting was performed to detect p53 expression in the presence of curcumin. (D) Western blotting was performed to detect p53 expression in the presence of various concentrations of curcumin. ${ }^{* *} \mathrm{P}<0.01 ;{ }^{* * * *} \mathrm{P}<0.0001$. SD, standard deviation.
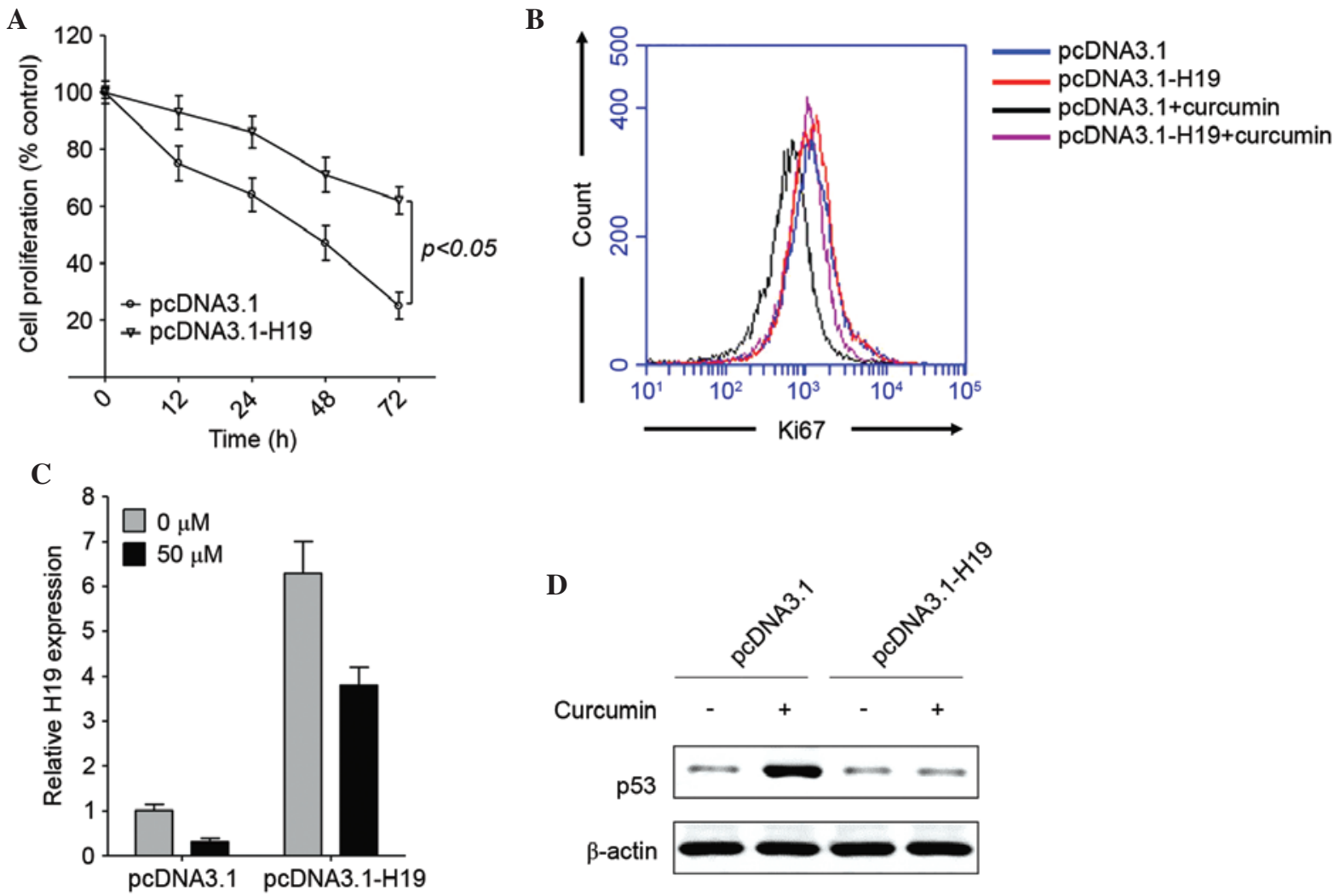

Figure 2. Ectopic expression of H19 enhances cell proliferation in the presence of curcumin. (A) SGC7901 cells were plated into 96-well plates and transfected with pcDNA3.1-H19 plasmid or empty vector control, after which the cells were treated with $50 \mu \mathrm{M}$ curcumin for various durations. Cell proliferation was determined using cell counting kit-8 assays. SGC7901 cells were plated into 24-well plates and transfected with pcDNA3.1-H19 plasmid or empty vector control, and then cells were treated with or without $50 \mu \mathrm{M}$ curcumin for $72 \mathrm{~h}$. (B) Ki67 expression was detected by flow cytometry. The relative expression levels of (C) H19 mRNA and (D) p53 protein were determined by reverse transcription-quantitative polymerase chain reaction and western blotting, respectively. Data are shown as the mean \pm standard deviation of three separate experiments performed in duplicate.

blocked with $5 \%$ nonfat milk and incubated with diluted antibodies at $4^{\circ} \mathrm{C}$ overnight. Primary antibodies against p53 (1:1,000; cat. no. 1C12), Bax (1:1,000; cat. no. D2E11), Bcl-2 (1:1,000; cat. no. 50E3), c-Myc (1:1,000; cat. no. D84C12) and $\beta$-actin $(1: 1,000$; cat. no. 13E5) were purchased from
Cell Signaling Technology, Inc. (Danvers, MA, USA). Subsequently, the membranes were incubated with a horseradish peroxidase-conjugated secondary antibody (1:2,000; cat. no., sc-2055; Santa Cruz Biotechnology, Inc., Dallas, TX, USA) at $37^{\circ} \mathrm{C}$ for $1 \mathrm{~h}$. The immunoreactive bands were visualized using 
A

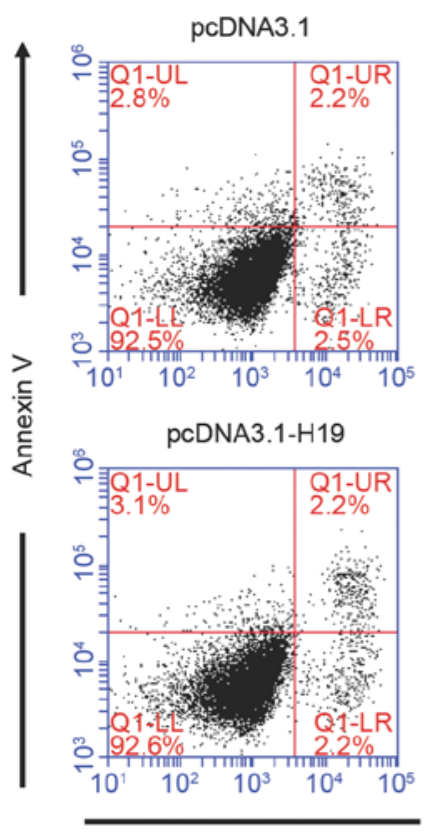

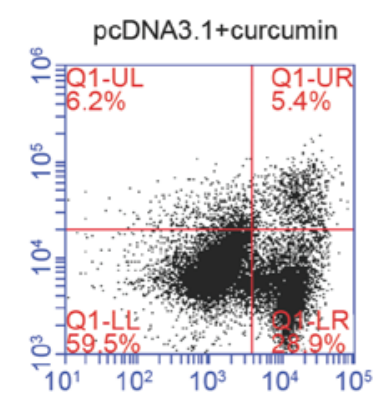

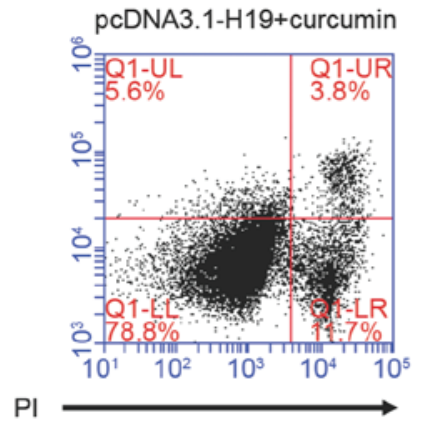

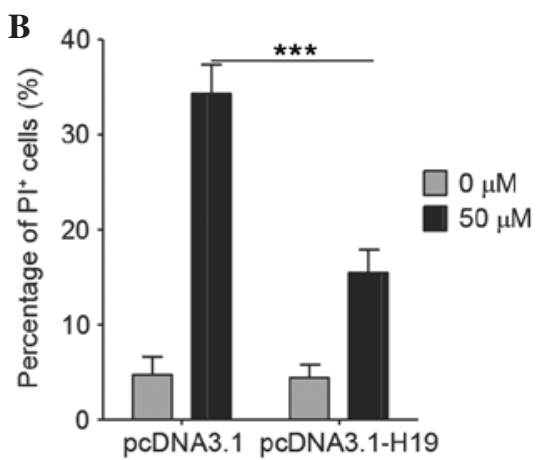

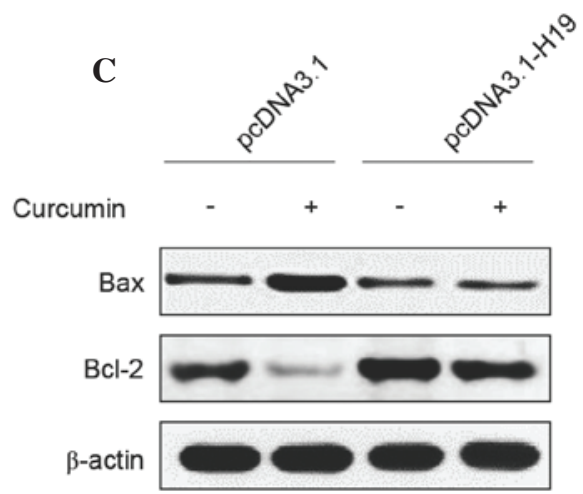

Figure 3. Ectopic expression of H19 inhibits cell apoptosis induced by curcumin. SGC7901 cells were plated onto 24-well plates and transfected with pcDNA3.1-H19 plasmid or empty vector control, after which the cells were treated with or without $50 \mu \mathrm{M}$ curcumin for $48 \mathrm{~h}$. (A) Cell apoptosis was determined by Annexin V and PI double staining. (B) PI positive cells were calculated. Data are shown as the mean \pm standard deviation of three separate experiments performed in duplicate. (C) Bax and Bcl-2 expression was determined by western blotting. ${ }^{* * *} \mathrm{P}<0.0001$. PI,propidium iodide; Bcl-2, B-cell lymphoma-2; Bax, Bcl-2-associated X protein.

the Immobilon ${ }^{\mathrm{TM}}$ Western Chemiluminescent HRP Substrate (EMD Millipore) and the UVP Bioimaging system (UVP, Inc., Upland, CA, USA).

Statistical analysis. All experiments were performed three times. Data are presented as the mean \pm standard deviation and analyzed using GraphPad Prism 5.00 software (GraphPad Software, Inc., La Jolla, CA, USA). Differences among the groups were assessed by one-way analysis of variance followed by Neuman-Keuls post-hoc test. $\mathrm{P}<0.05$ was considered to indicate a statistically significant difference.

\section{Results}

Curcumin inhibits gastric cancer cell proliferation and H19 expression. Initially, the effect of curcumin on the proliferation of the gastric cancer cell line SGC7901 was analyzed by CCK- 8 assays in the presence of various concentrations of curcumin for 12, 24, 48 and $72 \mathrm{~h}$. As shown in Fig. 1A, curcumin inhibited the growth of SGC7901 cells in a concentration- and a time-dependent manner. In comparison with the untreated cells, cell proliferation was significantly inhibited after $48 \mathrm{~h}$ of treatment with $50 \mu \mathrm{M}$ curcumin $(\mathrm{P}<0.01)$. The relative mRNA expression level of $\mathrm{H} 19$ was decreased in a dose-dependent manner following treatment with various concentrations of curcumin (Fig. 1B), and, as compared with SGC7901 cells in the absence of curcumin, showed the lowest level at $50 \mu \mathrm{M}(\mathrm{P}<0.0001)$. As for $\mathrm{p} 53$ expression in SGC7901 cells, curcumin markedly increased the expression level of p53 after $12 \mathrm{~h}$ (Fig. 1C and attained a peak at $48 \mathrm{~h}$ following treatment with $25 \mu \mathrm{M}$ curcumin (Fig. 1D).

Ectopic expression of $H 19$ reverses curcumin-mediated inhibition of proliferation. To further elucidate the role of H19 in curcumin-induced proliferative inhibition of gastric cancer cells, H19 was overexpressed in SGC7901 cells, which were subsequently treated with $50 \mu \mathrm{M}$ curcumin, as this concentration of curcumin induced the highest level of proliferative inhibition (Fig. 1A). As compared with the empty vector control, ectopic expression of H19 significantly enhanced cell proliferation in the presence of curcumin, as determined using the CCK-8 assay $(\mathrm{P}<0.05$; Fig. $2 \mathrm{~A})$ or Ki67 staining (Fig. 2B), which is a nuclear antigen only present in proliferating cells (36). In pcDNA3.1-H19-transfected cells, curcumin downregulated H19 expression (Fig. 2C), but did not enhance p53 expression (Fig. 2D). As H19 directly binds to p53 and deactivates p53 expression (26), curcumin may depend on the inhibition of $\mathrm{H} 19$ expression to enhance the tumor-suppressive activity of p53. These results suggest that curcumin enhances p53 expression by downregulating H19 expression.

Ectopic expression of $H 19$ reverses curcumin-induced cell apoptosis. Subsequently, the role of H19 in curcumin-induced apoptosis of SGC7901 cells was analyzed. As shown in Fig. 3A and B, there was no significant difference in cell apoptosis between the cells transfected with empty vector and pcDNA3.1-H19 (PI-positive, 4.7 vs. 4.4\%), which suggested that plasmid transfection did not induce a difference in cell 

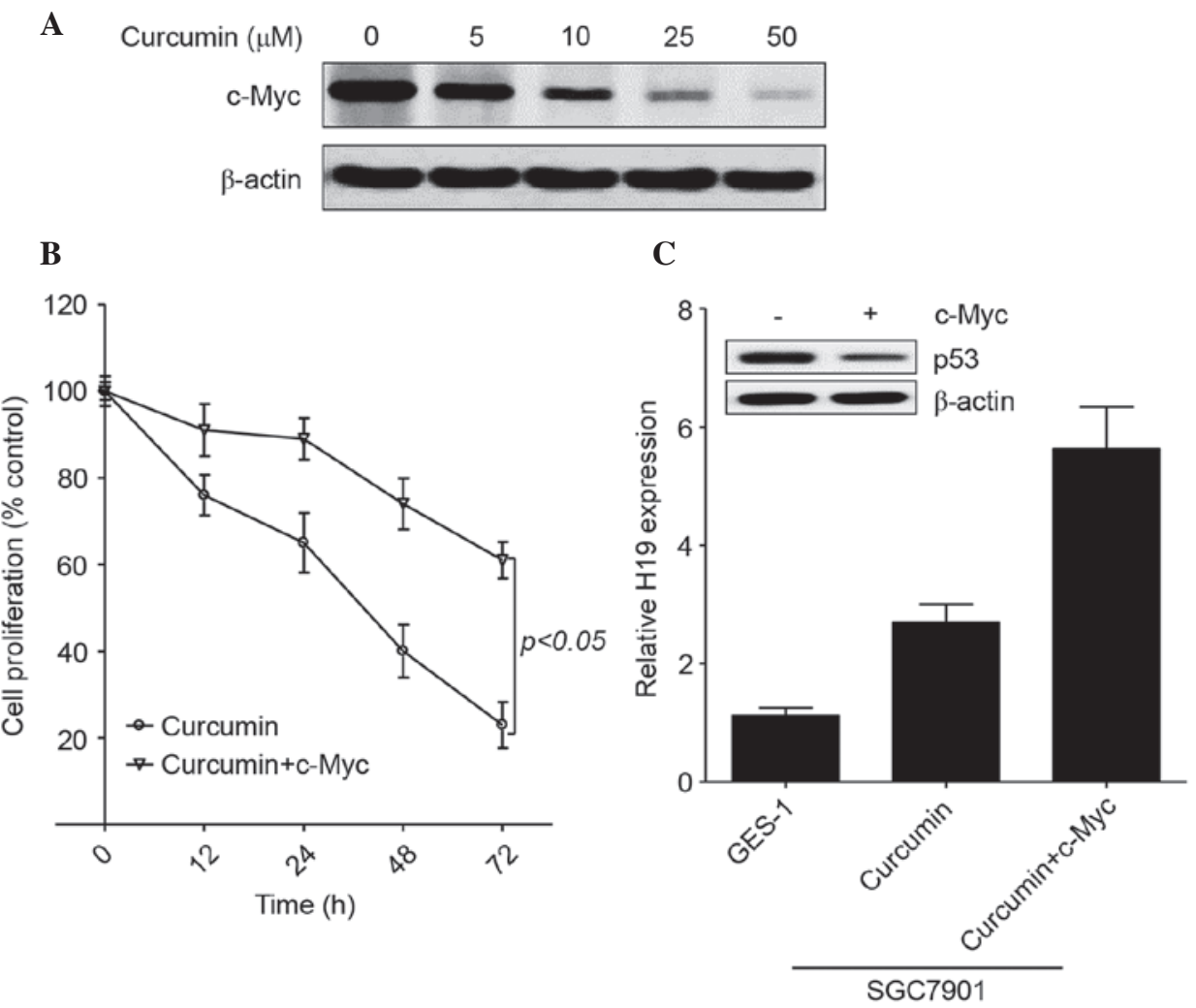

Figure 4. Effect of c-Myc on H19 and p53 expression in curcumin-treated cells. (A) SGC7901 cells were plated into 24-well plate and treated with different concentrations of curcumin for $48 \mathrm{~h}$, after which the protein expression of c-Myc was determined by western blotting. (B) SGC7901 cells were plated into 96-well plates and treated by $50 \mu \mathrm{M}$ curcumin with or without exogenous c-Myc $(5 \mu \mathrm{gml})$ for various durations. Cell proliferation was determined by cell counting kit-8 assays. Data are shown as the mean \pm SD of three separate experiments performed in duplicate. (C) SGC7901 cells were plated into 24-well plates and treated with $50 \mu \mathrm{M}$ curcumin with or without exogenous c-Myc $(5 \mu \mathrm{gml})$ for $48 \mathrm{~h}$. The relative mRNA expression levels of H19 were determined by reverse transcription-quantitative polymerase chain reaction. H19 levels were normalized to the GAPDH level in GES-1 cells. Data are shown as the mean \pm SD of three separate experiments performed in duplicate. Protein expression of p53 was determined by western blotting.

apoptosis. Curcumin significantly induced the apoptosis of cells transfected with empty vector $(\sim 34.3 \%$ were PI-positive), whereas, in H19-transfected cells, the percentage of apoptotic cells was $\sim 15.5 \%$, which was significantly lower compared with cells transfected with empty vector $(\mathrm{P}<0.0001)$. An increase in the ratio of $\mathrm{Bax} / \mathrm{Bcl}-2$ is known to initiate apoptosis (17); it was noted that curcumin markedly increased Bax expression and decreased Bcl-2 expression in empty vector-transfected cells, while this effect was almost diminished in H19-overexpressed cells (Fig. 3C). These results suggest that curcumin induces cell apoptosis by downregulating H19 expression.

c-Myc enhances H19 expression in curcumin-treated gastric cancer cells. As an oncogene, the expression of c-Myc has been shown to be upregulated in patients with gastric cancer and to induce H19 expression in gastric cancer cells $(29,30)$. Furthermore, curcumin inhibited c-Myc expression in $\mathrm{Bcl}$ and skin cancer $(2,28)$. Therefore, the present study further evaluated the role of c-Myc in regulating H19 expression in the presence of curcumin. As shown in Fig. 4A, curcumin markedly decreased c-Myc expression in gastric cancer cells in a concentration-dependent manner. Similar to H19, exogenous c-Myc induced cell proliferation in the presence of $50 \mu \mathrm{M}$ curcumin (Fig. 4B). In addition, exogenous c-Myc enhanced $\mathrm{H} 19$ expression and decreased p53 expression in curcumin-treated SGC7901 cells (Fig. 4C). These results confirm that curcumin inhibits $\mathrm{H} 19$ expression by regulating c-Myc expression in gastric cancer.

\section{Discussion}

Gastric cancer is the fifth most common malignancy and the third leading cause of cancer-associated mortality worldwide, with an estimated 952,000 new cases diagnosed and 723,000 deaths registered in 2012 (37). Previous studies have demonstrated that $\mathrm{H} 19$ plays an oncogenic role in gastric cancer and predicts a poor prognosis in patients with gastric cancer $(25,26,29,33,38)$. However, an agent that is able to downregulate $\mathrm{H} 19$ expression in tumor cells has rarely been reported (39). The present study demonstrated that curcumin, a naturally occurring phytochemical, was able to inhibit H19 expression in gastric cancer cells and thereby induce apoptosis and inhibit cellular proliferation.

Curcumin is able to suppress the proliferation and survival of cancer cells by directly or indirectly binding to various targets, including transcription factors, growth factors and several proteins that are involved in cell signal transduction pathways (40). c-Myc is an important oncogene that has been shown to be downregulated by curcumin (2). Similarly, the present study observed that curcumin decreased c-Myc expression in a concentration-dependent manner in gastric cancer. c-Myc regulates numerous gene targets 
that subsequently execute its many biological activities, including cell proliferation, transformation, angiogenesis and apoptosis (41). Furthermore, elevated expression of c-Myc correlates with a poor prognosis in various cancers, including head and neck squamous cell carcinoma, breast cancer and hepatocellular carcinomas (42-45). The present study also demonstrated that exogenous c-Myc was able to reverse curcumin-induced proliferative inhibition in gastric cancer cells.

Previous studies have indicated that c-Myc promotes cancer progression by upregulating tumor-promotive lncRNAs, including prostate cancer gene expression marker 1 and HOX transcript antisense RNA $(46,47)$. In addition, c-Myc has been reported to directly bind to the promoter of H19 in order to induce its expression and potentiate tumor progression in primary breast and lung carcinomas (30). In gastric cancer, c-Myc has been shown to induce H19 expression, and its expression was positively correlated with H19 expression in gastric cancer patients (29). The present study demonstrated that exogenous c-Myc enhanced H19 expression in the presence of curcumin, which provided evidence to explain how curcumin inhibited H19 expression, and provides a direct molecular link between curcumin and H19. However, whether c-Myc is indispensable for curcumin to regulate $\mathrm{H} 19$-mediated p53 deactivation still needs to be clarified in future.

The role of H19 in the progression of gastric cancer may be due to its association with p53 (26). p53, which is an important tumor suppressor, plays a pivotal role in inhibiting the proliferation and inducing the apoptosis of cancer cells (11). In the present study, curcumin significantly enhanced p53 expression, and simultaneously induced cell apoptosis and inhibited proliferation of gastric cancer cells. Conversely, ectopic expression of H19 abrogated curcumin-induced p53 expression, and the following effects on proliferation and apoptosis of cancer cells.

In conclusion, the major findings of this study can be summarized as follows: i) Curcumin inhibits H19 expression in gastric cancer cells; ii) H19 plays a pivotal role in curcumin-induced proliferative inhibition and apoptosis of gastric cancer cells; and iii) c-Myc can be downregulated by curcumin and is an important mediator between curcumin and H19. To the best of our knowledge, the present study demonstrated, for the first time, a novel mechanism by which curcumin exploits a lncRNA to inhibit gastric cancer growth. Therefore, curcumin may be considered a value therapeutic strategy for the treatment of gastric cancer.

\section{Acknowledgements}

This study was supported by the National Natural Science Foundation of China (grant no. 81370562).

\section{References}

1. Bar-Sela G, Epelbaum R and Schaffer M: Curcumin as an anti-cancer agent: Review of the gap between basic and clinical applications. Curr Med Chem 17: 190-197, 2010.

2. Han SS, Chung ST, Robertson DA, Ranjan D and Bondada S: Curcumin causes the growth arrest and apoptosis of B cell lymphoma by downregulation of egr-1, c-myc, bcl-XL, NF-kappa B, and p53. Clin Immunol 93: 152-161, 1999.
3. Dhillon N, Aggarwal BB, Newman RA, Wolff RA, Kunnumakkara AB, Abbruzzese JL, Ng CS, Badmaev V and Kurzrock R: Phase II trial of curcumin in patients with advanced pancreatic cancer. Clin Cancer Res 14: 4491-4499, 2008.

4. Sharma RA, Euden SA, Platton SL, Cooke DN, Shafayat A, Hewitt HR, Marczylo TH, Morgan B, Hemingway D, Plummer SM, et al: Phase I clinical trial of oral curcumin: Biomarkers of systemic activity and compliance. Clin Cancer Res 10: 6847-6854, 2004

5. Carroll RE, Benya RV, Turgeon DK, Vareed S, Neuman M, Rodriguez L, Kakarala M, Carpenter PM, McLaren C, Meyskens FL Jr and Brenner DE: Phase IIa clinical trial of curcumin for the prevention of colorectal neoplasia. Cancer Prev Res (Phila) 4: 354-364, 2011.

6. Goel A, Boland CR and Chauhan DP: Specific inhibition of cyclooxygenase-2 (COX-2) expression by dietary curcumin in HT-29 human colon cancer cells. Cancer Lett 172: 111-118, 2001.

7. Wang Z, Zhang Y, Banerjee S, Li Y and Sarkar FH: Notch-1 down-regulation by curcumin is associated with the inhibition of cell growth and the induction of apoptosis in pancreatic cancer cells. Cancer 106: 2503-2513, 2006.

8. Marin YE, Wall BA, Wang S, Namkoong J, Martino JJ, Suh J, Lee HJ, Rabson AB, Yang CS, Chen S and Ryu JH: Curcumin downregulates the constitutive activity of NF-kappaB and induces apoptosis in novel mouse melanoma cells. Melanoma Res 17: 274-283, 2007.

9. Nagamine M, Okumura T, Tanno S, Sawamukai M, Motomura W, Takahashi N and Kohgo Y: PPAR gamma ligand-induced apoptosis through a p53-dependent mechanism in human gastric cancer cells. Cancer Sci 94: 338-343, 2003.

10. Choudhuri T, Pal S, Agwarwal ML, Das T and Sa G: Curcumin induces apoptosis in human breast cancer cells through p53-dependent Bax induction. FEBS Lett 512: 334-340, 2002.

11. Choudhuri T, Pal S, Das T and Sa G: Curcumin selectively induces apoptosis in deregulated cyclin D1-expressed cells at G2 phase of cell cycle in a p53-dependent manner. J Biol Chem 280: 20059-20068, 2005.

12. Sintara K, Thong-Ngam D, Patumraj S and Klaikeaw N: Curcumin attenuates gastric cancer induced by $\mathrm{N}$-methyl-N-nitrosourea and saturated sodium chloride in rats. J Biomed Biotechnol 2012: 915380, 2012.

13. Cai XZ, Wang J, Li XD, Wang GL, Liu FN, Cheng MS and Li F: Curcumin suppresses proliferation and invasion in human gastric cancer cells by downregulation of PAK1 activity and cyclin D1 expression. Cancer Biol Ther 8: 1360-1368, 2009.

14. Cai XZ, Huang WY, Qiao Y, Du SY, Chen Y, Chen D, Yu S, Che RC, Liu N and Jiang Y: Inhibitory effects of curcumin on gastric cancer cells: A proteomic study of molecular targets. Phytomedicine 20: 495-505, 2013.

15. Liang T, Zhang X, Xue W, Zhao S, Zhang X and Pei J: Curcumin induced human gastric cancer BGC-823 cells apoptosis by ROS-mediated ASK1-MKK4-JNK stress signaling pathway. Int J Mol Sci 15: 15754-15765, 2014.

16. Song G, Ming Y, Mao Y, Bao S and Ouyang G: Osteopontin prevents curcumin-induced apoptosis and promotes survival through Akt activation via alpha $v$ beta 3 integrins in human gastric cancer cells. Exp Biol Med (Maywood) 233: 1537-1545, 2008.

17. Tanigawa S, Fujii M and Hou DX: Stabilization of p53 is involved in quercetin-induced cell cycle arrest and apoptosis in HepG2 cells. Biosci Biotechnol Biochem 72: 797-804, 2008.

18. Xing CG, Zhu BS, Liu HH, et al: LY294002 induces p53-dependent apoptosis of SGC7901 gastric cancer cells. Acta pharmacologica Sinica 29: 489-498, 2008.

19. Adriaenssens E, Dumont L, Lottin S, Bolle D, Leprêtre A, Delobelle A, Bouali F, Dugimont T, Coll J and Curgy JJ: H19 overexpression in breast adenocarcinoma stromal cells is associated with tumor values and steroid receptor status but independent of p53 and Ki-67 expression. Am J Pathol 153: 1597-1607, 1998.

20. Ariel I, Miao HQ, Ji XR, Schneider T, Roll D, de Groot N, Hochberg A and Ayesh S: Imprinted H19 oncofetal RNA is a candidate tumour marker for hepatocellular carcinoma. Mol Pathol 51: 21-25, 1998.

21. Luo M, Li Z, Wang W, Zeng Y, Liu Z and Qiu J: Long non-coding RNA H19 increases bladder cancer metastasis by associating with EZH2 and inhibiting E-cadherin expression. Cancer Lett 333: 213-221, 2013.

22. Shi Y, Wang Y, Luan W, Wang P, Tao T, Zhang J, Qian J, Liu N and You Y: Long non-coding RNA H19 promotes glioma cell invasion by deriving miR-675. PLoS One 9: e86295, 2014. 
23. Wang J, Song YX and Wang ZN: Non-coding RNAs in gastric cancer. Gene 560: 1-8, 2015.

24. Li PF, Chen SC, Xia T, Jiang XM, Shao YF, Xiao BX and Guo JM: Non-coding RNAs and gastric cancer. World J Gastroenterol 20: 5411-5419, 2014

25. Song H, Sun W, Ye G, Ding X, Liu Z, Zhang S, Xia T, Xiao B, $\mathrm{Xi} Y$ and Guo J: Long non-coding RNA expression profile in human gastric cancer and its clinical significances. J Transl Med 11: 225, 2013.

26. Yang F, Bi J, Xue X, Zheng L, Zhi K, Hua J and Fang G: Up-regulated long non-coding RNA H19 contributes to proliferation of gastric cancer cells. FEBS J 279: 3159-3165, 2012.

27. Novak Kujundzić R, Grbesa I, Ivkić M, Katdare M and Gall-Troselj K: Curcumin downregulates H19 gene transcription in tumor cells. J Cell Biochem 104: 1781-1792, 2008.

28. Kakar SS and Roy D: Curcumin inhibits TPA induced expression of c-fos, c-jun and c-myc proto-oncogenes messenger RNAs in mouse skin. Cancer Lett 87: 85-89, 1994.

29. Zhang EB, Han L, Yin DD, Kong R, De W and Chen J: c-Myc-induced, long, noncoding $\mathrm{H} 19$ affects cell proliferation and predicts a poor prognosis in patients with gastric cancer. Med Oncol 31: 914, 2014.

30. Barsyte-Lovejoy D, Lau SK, Boutros PC, Khosravi F, Jurisica I, Andrulis IL, Tsao MS and Penn LZ: The c-Myc oncogene directly induces the H19 noncoding RNA by allele-specific binding to potentiate tumorigenesis. Cancer Res 66: 5330-5337, 2006.

31. Geiler C, Andrade I and Greenwald D: Exogenous c-Myc Blocks Differentiation and Improves Expansion of Human Erythroblasts In vitro. International journal of stem cells 7: 153-157, 2014.

32. Tsang WP, Ng EK, Ng SS, Jin H, Yu J, Sung JJ and Kwok TT: Oncofetal H19-derived miR-675 regulates tumor suppressor RB in human colorectal cancer. Carcinogenesis 31: 350-358, 2010.

33. Zhuang M, Gao W, Xu J, Wang P and Shu Y: The long non-coding RNA H19-derived miR-675 modulates human gastric cancer cel proliferation by targeting tumor suppressor RUNX1. Biochem Biophys Res Commun 448: 315-322, 2014.

34. Livak KJ and Schmittgen TD: Analysis of relative gene expression data using real-time quantitative PCR and the 2(-Delta Delta C(T)) Method. Methods 25: 402-408, 2001.

35. Xie B, Zhou J, Shu G, Liu DC, Zhou J, Chen J and Yuan L: Restoration of klotho gene expression induces apoptosis and autophagy in gastric cancer cells: Tumor suppressive role of klotho in gastric cancer. Cancer Cell Int 13: 18, 2013.
36. Li N, Deng W, Ma J, et al: Prognostic evaluation of Nanog, Oct4, Sox2, PCNA, Ki67 and E-cadherin expression in gastric cancer. Med Oncol 32: 433, 2015.

37. Ferlay J, Soerjomataram I, Dikshit R, Eser S, Mathers C, Rebelo M, Parkin DM, Forman D and Bray F: Cancer incidence and mortality worldwide: Sources, methods and major patterns in GLOBOCAN 2012. Int J Cancer 136: E359-E386, 2015.

38. Li H, Yu B, Li J, Su L, Yan M, Zhu Z and Liu B: Overexpression of lncRNA H19 enhances carcinogenesis and metastasis of gastric cancer. Oncotarget 5: 2318-2329, 2014.

39. Sorin V, Ohana P, Mizrahi A, et al: Regional therapy with DTA-H19 vector suppresses growth of colon adenocarcinoma metastases in the rat liver. International journal of oncology 39: 1407-1412, 2011.

40. Zang S, Liu T, Shi J and Qiao L: Curcumin: A promising agent targeting cancer stem cells. Anticancer Agents Med Chem 14: 787-792, 2014

41. Dang CV: c-Myc target genes involved in cell growth, apoptosis, and metabolism. Mol Cell Biol 19: 1-11, 1999.

42. Field JK, Spandidos DA, Stell PM, Vaughan ED, Evan GI and Moore JP: Elevated expression of the c-myc oncoprotein correlates with poor prognosis in head and neck squamous cell carcinoma. Oncogene 4: 1463-1468, 1989.

43. Deming SL, Nass SJ, Dickson RB and Trock BJ: C-myc amplification in breast cancer: A meta-analysis of its occurrence and prognostic relevance. Br J Cancer 83: 1688-1695, 2000.

44. Nair R, Roden DL, Teo WS, McFarland A, Junankar S, Ye S, Nguyen A, Yang J, Nikolic I, Hui M, et al: c-Myc and Her2 cooperate to drive a stem-like phenotype with poor prognosis in breast cancer. Oncogene 33: 3992-4002, 2014.

45. Jang KY, Noh SJ, Lehwald N, Tao GZ, Bellovin DI, Park HS, Moon WS, Felsher DW and Sylvester KG: SIRT1 and c-Myc promote liver tumor cell survival and predict poor survival of human hepatocellular carcinomas. PLoS One 7: e45119, 2012.

46. Ma MZ, Li CX, Zhang Y, Weng MZ, Zhang MD, Qin YY, Gong W and Quan ZW: Long non-coding RNA HOTAIR, a c-Myc activated driver of malignancy, negatively regulates miRNA-130a in gallbladder cancer. Mol Cancer 13: 156, 2014.

47. Hung CL, Wang LY, Yu YL, Chen HW, Srivastava S, Petrovics $\mathrm{G}$ and Kung HJ: A long noncoding RNA connects c-Myc to tumor metabolism. Proc Natl Acad Sci USA 111: 18697-18702, 2014. 